TELEMATIKA, Vol. 06, No. 02, JANUARI, 2010, Pp. 49 - 58

ISSN 1829-667X

\title{
TEKNIK PERMODELAN ANALITYCAL HIERARCHY PROCES (AHP) SEBAGAI PENDUKUNG KEPUTUSAN
}

\author{
Nur Heri Cahyana \\ Jurusan Teknik Informatika UPN "Veteran" Yogyakarta \\ e-mail : omyon 45@Yahoo.com
}

\begin{abstract}
Analitycal Hierarchy Process (AHP) a model with the functional hierarchy where input of the core importants human being perception. By hierarki, an complex problem and structure do not solved by into group

Analytical decision-making processes will phase as follows : developing model from problem, determining criterion, paying attention to existing constraint, and [doing/conducting] optimasi.

Analitycal Hierarchy Process can solve problem complex where aspect or criterion taken by quite a lot.

Keyword : AHP, SPK, Decision, Weight

Analitycal Hierarchy Proses (AHP) sebuah model dengan hirarki fungsional dimana input utamanya adalah persepsi manusia. Dengan hirarki, suatu masalah kompleks dan tidak terstruktur dipecahkan kedalam kelompok.

Proses pengambilan keputusan analitis akan melalui tahap mengembangkan model dari masalah, menentukan kriteria, memperhatikan kendala yang ada, dan melakukan optimasi.

Analitycal Hierarchy Proces dapat memecahkan masalah yang kompleks dimana aspek atau kriteria yang diambil cukup banyak.

Kata Kunci : AHP, SPK, Keputusan, pembobotan
\end{abstract}

\section{Pendahuluan}

Secara ideal, komponen pemodelan suatu Sistem Pendukung Keputusan (SPK) harus bisa menunjang setiap aktivitas pengambilan keputusan yang meliputi analisis system permasalahan, proyeksi situasi masa depan, perancangan alternatif, pembandingan atau pemilihan alternatif, optimasi dan simulasi melalui penerapan model-model yang relevan.

Model-model dalam SPK dirancang sedemikian rupa sehinga untuk setiap basis model, pengambil keputusan dapat menentukan sendiri parameter-parameter model yang digunakan, tahapan atau algoritma yang akan dijalani oleh proses permodelan yang bersangkutan melalui komponen dialog. Metode ini diambil untuk mendapatkan sistem pendukung kegiatan permodelan yang fleksibel.

Proses pengambilan keputusan pada dasarnya adalah memilih suatu alternatif, peralatan utama AHP adalah sebuah hirarki fungsional dengan input utamanya persepsi manusia dengan hirarki, suatu masalah komplek dan tidak terstruktur, dipecahkan ke dalam kelompok-kelompok, kemudian kelompok diatur menjadi suatu hirarki (permadi1992).

\section{Tinjauan Pustaka}

Kualitas dari suatu keputusan yang diambil dari korelasi kuat dengan suatu perubahan arah dan proses dari sesuatu hal yang sedang dilakukan, bahkan hal tersebut dapat mempengaruhi kualitas ataupun kuantitas dari suatu tujuan (goal).

AHP merupakan suatu metode yang dapat memecahkan masalah yang kompleks, dimana aspek yang diambil cukup banyak. Kompleksitas ini juga disebabkan oleh struktur masalah yang belum jelas, ketidakpastian persepsi pengambil keputusan serta ketidakpastian tersedianya data statistik yang tidak akurat atau bahkan tidak ada sama sekali.

Dalam penelitian ini akan dibahas bagaimana merancang sebuah teknik permodelan dengan metoda Analytical Hirarchy Proces yang digunakan dalam mendukung pengambilan keputusan.

\section{Penjabaran Hirarki Tujuan}

Dalam penjabaran hirarki tujuan, tidak ada pedoman yang pasti seberapa jauh pengambil keputusan menjabarkan tujuan menjadi tujuan yang lebih rendah. Pengambil keputusanlah 
yang menentukan saat penjabaran tujuan ini berhenti, dengan memperhatikan keuntungan atau kekurangan yang diperoleh bila tujuan tersebut diperinci lebih lanjut.

\section{Tahapan AHP}

AHP memiliki kemampuan memecahkan masalah yang multi obyektif dan multi criteria berdasarkan pada preferensi dari setiap elemen dalam hirarki. Berikut ini merupakan langkahlangkah AHP :

1) Membuat struktur hirarki yang diawali dengan tujuan umum, dilanjutkan dengan subtujuan-subtujuan, kriteria dan kemungkinan alternatif-alternatif pada tingkatan kriteria yang paling bawah.

2) Membuat matriks perbandingan berpasangan pada intensitas. Perbandingan dilakukan berdasarkan "judgment" dari pengambil keputusan dengan menilai tingkat kepentingan suatu elemen dibandingkan elemen lainnya. Sehingga diperoleh judgment seluruhnya sebanyak $n *[(n-1) / 2]$ buah, dengan $n$ adalah banyaknya elemen yang dibandingkan. Kemudian menentukan prioritas lokalnya dan menghitung konsistensinya.

3) Melakukan operasi perkalian antara matriks yang memuat prioritas lokal kriteria dengan matriks yang memuat prioritas lokal intensitas / alternatif sehingga akhirnya akan menghasilkan suatu prioritas global.

4) Memeriksa elemen matriks jika $a_{i j}{ }^{*} a_{j k}=a_{i k}$ maka penilaian pada matriks tersebut sudah konsisten jika tidak maka lakukan perhitungan dengan rumus untuk menghitung konsistensi rasionya. Jika nilainya lebih dari 10 persen maka penilaian data judgment harus diperbaiki.

Secara naluri, manusia dapat mengestimasi besaran sederhana melalui inderanya. Proses yang paling mudah adalah membandingkan dua hal dengan keakuratan perbandingan yang dapat dipertanggungjawabkan. Skala kuantitatif 1 sampai dengan 9 untuk menilai perbandingan tingkat kepentingan suatu elemen terhadap elemen lain.(Saaty,1988)

Tabel 1. Skala Penilaian Perbandingan Pasangan

\begin{tabular}{|c|c|c|}
\hline $\begin{array}{l}\text { Intensitas } \\
\text { Kepentingan }\end{array}$ & Keterangan & Penjelasan \\
\hline 1 & Kedua elemen sama penting & $\begin{array}{l}\text { Dua elemen mempunyai pengaruh } \\
\text { yang sama besar terhadap tujuan }\end{array}$ \\
\hline 2 & $\begin{array}{l}\text { Elemen yang satu sedikit lebih } \\
\text { penting daripada elemen yang } \\
\text { lainnya }\end{array}$ & $\begin{array}{l}\text { Pengalaman dan penilaian sedikit } \\
\text { menyokong satu elemen dibandingkan } \\
\text { elemen lainnya }\end{array}$ \\
\hline 5 & $\begin{array}{l}\text { Elemen yang satu lebih penting } \\
\text { daripada elemen yang lainnya }\end{array}$ & $\begin{array}{l}\text { Pengalaman dan penilaian sangat kuat } \\
\text { menyokong satu elemen dibandingkan } \\
\text { elemen lainnya }\end{array}$ \\
\hline 7 & $\begin{array}{l}\text { Satu elemen jelas lebih mutlak } \\
\text { penting daripada elemen lainnya }\end{array}$ & $\begin{array}{l}\text { Satu elemen yang kuat disokong dan } \\
\text { dominan terlihat dalam praktek }\end{array}$ \\
\hline 9 & $\begin{array}{l}\text { Satu elemen mutlak penting } \\
\text { daripada elemen lainnya }\end{array}$ & $\begin{array}{l}\text { Bukti yang mendukung elemen yang } \\
\text { satu terhadap elemen lain memiliki } \\
\text { tingkat penegasan tertinggi yang } \\
\text { mungkin menguatkan }\end{array}$ \\
\hline $2,4,6,8$ & $\begin{array}{l}\text { Nilai-nilai antara dua nilai } \\
\text { pertimbangan yang berdekatan }\end{array}$ & $\begin{array}{l}\text { Nilai ini diberikan bila ada dua } \\
\text { kompromi diantara dua pilihan }\end{array}$ \\
\hline Kebalikan & \multicolumn{2}{|c|}{$\begin{array}{l}\text { Jika untuk aktivitas i mendapat satu angka dibanding dengan aktivitas j, } \\
\text { maka j mempunyai nilai kebalikannya dibanding dengan i }\end{array}$} \\
\hline
\end{tabular}

*sumber : Sistem Pendukung Keputusan, Kadarsah, 2002

Untuk menghitung konsistensi dari matriks perbandingan berpasangan dibutuhkan consistency random (CR). Berdasarkan perhitungan Saaty dengan menggunakan 500 sampel, jika "judgment" numerik diambil secara acak dari skala 1/9, 1/8, .., 1, 2, ., 9 akan diperoleh rata-rata konsistensi untuk matriks dengan ukuran yang berbeda. Pada tabel 2.2 akan dijelaskan masing-masing ukuran matriks memiliki nilai indeks konsistesi. 
Tabel 2. Nilai Konsistensi Random

\begin{tabular}{|c|c|}
\hline Ukuran matriks & Consistency Index \\
\hline 1,2 & 0.00 \\
\hline 3 & 0.58 \\
\hline 4 & 0.90 \\
\hline 5 & 1.12 \\
\hline 6 & 1.24 \\
\hline 7 & 1.32 \\
\hline 8 & 1.41 \\
\hline 9 & 1.45 \\
\hline 10 & 1.49 \\
\hline 11 & 1.51 \\
\hline 12 & 1.48 \\
\hline 13 & 1.56 \\
\hline 14 & 1.57 \\
\hline 15 & 1.59 \\
\hline
\end{tabular}

*sumber : Sistem Pendukung Keputusan, Kadarsah, 2002

\section{Penggunaan Metode AHP}

Contoh penggunaan metode AHP adalah pada masalah pemilihan sekolah yang dilakukan oleh Prof. T.L. Saaty, penemu model AHP, untuk membantu anaknya dalam menentukan perguruan tinggi mana yang akan dimasukinya setelah lulus dari sekolah menengah atas.

Kriteria-kriteria yang dikembangkan dalam memilih sekolah adalah proses belajar mengajar, lingkungan pergaulan, kehidupan sekolah secara umum, pendidikan kejuruan, persiapan atau kualifikasi yang diminta, dan mutu kelas musiknya. Sedangkan alternatifnya yaitu 3 perguruan tinggi yang akan dipilih sebut saja perguruan tinggi $A$, perguruan tinggi $B$, dan perguruan tinggi $\mathrm{C}$.

Selanjutnya dengan memulai tahapan-tahapan metode AHP untuk contoh kasus tersebut, berikut tahapannya :

1. Membuat struktur hirarki yang diawali dengan tujuan, dilanjutkan dengan kriteria dan kemungkinan alternatif-alternatif pada tingkatan kriteria yang paling bawah.

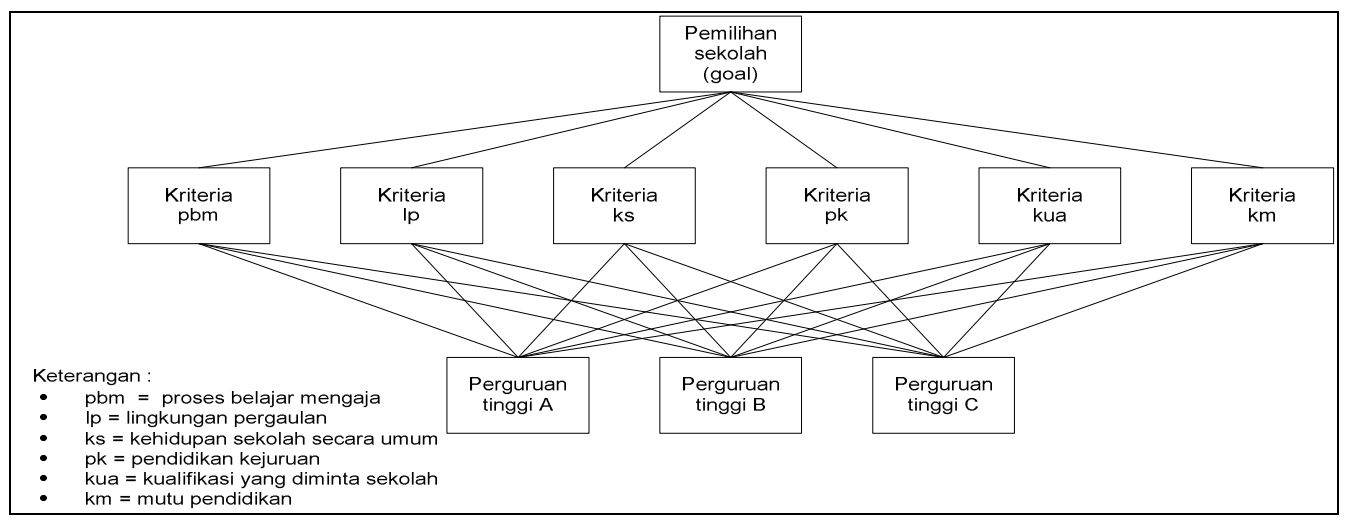

Gambar 1. Hirarki Tujuan Pemilihan Perguruan Tinggi 
2. Setelah menyusun hirarki, menetapkan prioritas elemen dengan menentukan perbandingan berpasangan berdasarkan kepentingan relatif antar elemen dalam bentuk matriks sesuai dengan skala penilaian perbandingan pasangan.

Tabel 3. Matriks Perbandingan Kriteria

\begin{tabular}{|c|c|c|c|c|c|c|}
\hline & PBM & LP & KS & PK & KUA & KM \\
\hline PBM & 1 & 4 & 3 & 1 & 3 & 4 \\
\hline LP & 0.25 & 1 & 7 & 3 & 0.2 & 1 \\
\hline KS & 0.33 & 0.14 & 1 & 0.2 & 0.2 & 0.16 \\
\hline PK & 1 & 0.33 & 5 & 1 & 1 & 0.33 \\
\hline KUA & 0.33 & 5 & 5 & 1 & 1 & 3 \\
\hline KM & 0.25 & 1 & 6 & 3 & 0.33 & 1 \\
\hline
\end{tabular}

Kemudian untuk menentukan prioritas setiap kriteria dan menghitung konsistensinya. Berikut langkah-langkahnya :

a. Menjumlahkan nilai dari setiap elemen kolom, hasilnya dapat dilihat pada tabel dibawah ini.

Tabel 4. Matriks Penjumlahan Tiap Kolom

\begin{tabular}{|c|c|c|c|c|c|c|}
\hline & PBM & LP & KS & PK & KUA & KM \\
\hline PBM & 1 & 4 & 3 & 1 & 3 & 4 \\
\hline LP & 0.25 & 1 & 7 & 3 & 0.2 & 1 \\
\hline KS & 0.33 & 0.14 & 1 & 0.2 & 0.2 & 0.16 \\
\hline PK & 1 & 0.33 & 5 & 1 & 1 & 0.33 \\
\hline KUA & 0.33 & 5 & 5 & 1 & 1 & 3 \\
\hline KM & 0.25 & 1 & 6 & 3 & 0.33 & 1 \\
\hline Jumlah Per Kolom & 3.16 & 11.47 & 27 & 8.2 & 5.73 & 9.49 \\
\hline
\end{tabular}

b. Membagi setiap elemen pada kolom dengan jumlah per kolom yang sesuai, hasilnya dapat dilihat pada tabel berikut.

Tabel 5. Matriks Pembagian Setiap Elemen Dengan Nilai Jumlah Kolom

\begin{tabular}{|c|c|c|c|c|c|c|}
\hline & PBM & LP & KS & PK & KUA & KM \\
\hline PBM & 0.31 & 0.34 & 0.11 & 0.12 & 0.52 & 0.42 \\
\hline LP & 0.07 & 0.08 & 0.25 & 0.36 & 0.03 & 0.1 \\
\hline KS & 0.1 & 0.01 & 0.03 & 0.02 & 0.03 & 0.01 \\
\hline PK & 0.31 & 0.02 & 0.18 & 0.12 & 0.17 & 0.03 \\
\hline KUA & 0.1 & 0.43 & 0.18 & 0.12 & 0.17 & 0.31 \\
\hline KM & 0.07 & 0.08 & 0.22 & 0.36 & 0.05 & 0.1 \\
\hline
\end{tabular}


c. Jumlahkan tiap baris dan hasilnya bagi dengan banyak elemen $(n=6)$, maka didapatkan nilai prioritas untuk setiap kriteria dengan nilai prioritas tertinggi pada kriteria PBM, yang diikuti dengan KUA, LP, M, PK dan yang terakhir KS. Hasilnya dapat dilihat pada tabel beriku :

Tabel 6. Matriks Prioritas Kriteria

\begin{tabular}{|c|c|c|c|c|c|c|c|c|}
\hline & PBM & LP & KS & PK & KUA & KM & $\Sigma$ baris & Prioritas \\
\hline PBM & 0.31 & 0.34 & 0.11 & 0.12 & 0.52 & 0.42 & 1.82 & 0.303 \\
\hline LP & 0.07 & 0.08 & 0.25 & 0.36 & 0.03 & 0.1 & 0.89 & 0.148 \\
\hline KS & 0.1 & 0.01 & 0.03 & 0.02 & 0.03 & 0.01 & 0.2 & 0.033 \\
\hline PK & 0.31 & 0.02 & 0.18 & 0.12 & 0.17 & 0.03 & 0.83 & 0.138 \\
\hline KUA & 0.1 & 0.43 & 0.18 & 0.12 & 0.17 & 0.31 & 1.31 & 0.218 \\
\hline KM & 0.07 & 0.08 & 0.22 & 0.36 & 0.05 & 0.1 & 0.88 & 0.146 \\
\hline
\end{tabular}

d. Setelah didapatkan nilai prioritas setiap kriteria, kemudian dihitung nilai konsistensi rasionya dengan mengalikan nilai elemen-elemen pada matriks dengan prioritas yang bersesuaian. Hasilnya dapat dilihat pada tabel berikut :

Tabel 7. Matriks Perkalian Setiap Elemen dengan Nilai Prioritasnya

\begin{tabular}{|c|c|c|c|c|c|c|c|}
\hline & PBM & LP & KS & PK & KUA & KM & $\Sigma$ baris \\
\hline PBM & 0.303 & 0.592 & 0.099 & 0.138 & 0.654 & 0.584 & 2.37 \\
\hline LP & 0.075 & 0.148 & 0.231 & 0.414 & 0.043 & 0.146 & 1.057 \\
\hline KS & 0.099 & 0.020 & 0.033 & 0.027 & 0.043 & 0.023 & 0.245 \\
\hline PK & 0.303 & 0.048 & 0.165 & 0.138 & 0.218 & 0.048 & 0.920 \\
\hline KUA & 0.099 & 0.740 & 0.165 & 0.138 & 0.218 & 0.438 & 1.798 \\
\hline KM & 0.021 & 0.148 & 0.198 & 0.414 & 0.071 & 0.146 & 0.998 \\
\hline
\end{tabular}

Jumlah tiap baris dibagi dengan masing-masing prioritas yang bersesuaian dan hasilnya dijumlahkan. Hasil penjumlahan dibagi dengan banyak elemen $(n=6)$

Rumus $=\Sigma$ Baris $/$ Prioritas......

untuk mendapatkan $\lambda$ maks. Setelah itu dihitung indeks konsistensi $(\mathrm{Cl})$ dan rasio konsistensi (CR).

$\mathrm{PBM}=2.370 / 0.303=7.821$

LP $\quad=1.057 / 0.148=7.141$

$\mathrm{KS}=0.245 / 0.033=7.424$

$\mathrm{PK}=0.920 / 0.138=6.666$

$\mathrm{KUA}=1.798 / 0.218=8.247$

$\mathrm{KM}=0.998 / 0.146=6.835$

Total $=44.134$

$\lambda$ maks $=$ Total $/ \mathrm{n}$

$\lambda$ maks $=44.134 / 6=7.355$

Consistensy Indeks $(\mathrm{Cl})=(\lambda$ maks $-\mathrm{n}) /(\mathrm{n}-1)$

$\mathrm{Cl}=(7.355-6) / 5$

$$
=0.271
$$

Untuk $n=6$, Random Consistency-nya adalah 1.24

$\mathrm{CR}=\mathrm{Cl} / \mathrm{RC}$.

$\mathrm{CR}=0.271 / 1.24$

$$
=0.21
$$


Langkah $\mathrm{d}$ adalah untuk menentukan nilai konsistensi dari perbandingan berpasangan antar elemen kriteria. Rasio konsistensi yang dihasilkan dari perhitungan adalah 0.21 atau $21 \%$. maka data belum dibenarkan karena melewati batas rasio konsistensi.

3. Menentukan prioritas intensitas tiap kriteria.

a. Kriteria Proses Belajar Mengajar

Untuk kriteria proses belajar mengajar dilakukan dengan menentukan perbandingan berpasangan terhadap alternatif perguruan tinggi untuk menghitung prioritas dan ratio konsistensi. Hasilnya dapat dilihat pada tabel dibawah ini :

Tabel 8. Matriks Perbandingan Kepentingan Alternatif Berdasarkan Pertimbangan Proses Belajar Mengajar

\begin{tabular}{|c|c|c|c|c|}
\hline PBM & A & B & C & Prioritas \\
\hline A & 1 & 0.33 & 0.5 & 0.16 \\
\hline B & 3 & 1 & 3 & 0.59 \\
\hline C & 2 & 0.33 & 1 & 0.25 \\
\hline
\end{tabular}

$$
\text { CR }=1.638
$$

b. Kriteria Lingkungan Pergaulan

Untuk kriteria lingkungan pergaulan dilakukan dengan menentukan perbandingan berpasangan terhadap alternatif perguruan tinggi untuk menghitung prioritas dan ratio konsistensi. Hasilnya dapat dilihat pada tabel dibawah ini :

Tabel 9. Matriks Perbandingan Kepentingan Alternatif Berdasarkan Pertimbangan Lingkungan Pergaulan

\begin{tabular}{|c|c|c|c|c|}
\hline LP & A & B & C & Prioritas \\
\hline A & 1 & 1 & 1 & 0.33 \\
\hline B & 1 & 1 & 1 & 0.33 \\
\hline C & 1 & 1 & 1 & 0.33 \\
\hline
\end{tabular}

$$
\mathrm{CR}=\mathbf{0 . 0 2 6}
$$

c. Kriteria Kehidupan Secara Umum

Untuk kriteria kehidupan secara umum dilakukan dengan menentukan perbandingan berpasangan terhadap alternatif perguruan tinggi untuk menghitung prioritas dan rasio konsistensi. Hasilnya dapat dilihat pada tabel dibawah ini :

Tabel 10. Matriks Perbandingan Kepentingan Alternatif Berdasarkan Pertimbangan Kehidupan Sekolah Secara Umum

\begin{tabular}{|c|c|c|c|c|}
\hline KS & A & B & C & Prioritas \\
\hline A & 1 & 5 & 1 & 0.45 \\
\hline B & 0.2 & 1 & 0.2 & 0.09 \\
\hline C & 1 & 5 & 1 & 0.46 \\
\hline
\end{tabular}

d. Kriteria Pendidikan Kejuruan

CR $=0.0027$

Untuk kriteria pendidikan kejuruan dilakukan dengan menentukan perbandingan berpasangan terhadap alternatif perguruan tinggi untuk menghitung prioritas dan rasio konsistensi. Hasilnya dapat dilihat pada tabel dibawah ini : 
Tabel 11. Matriks Perbandingan Kepentingan Alternatif Berdasarkan Pertimbangan Pendidikan Kejuruan

\begin{tabular}{|c|c|c|c|c|}
\hline PK & A & B & C & Prioritas \\
\hline A & 1 & 9 & 7 & 0.77 \\
\hline B & 0.11 & 1 & 0.2 & 0.05 \\
\hline C & 0.14 & 5 & 1 & 0.17 \\
\hline
\end{tabular}

$C R=-0,1724$

e. Kriteria Kualifikasi Yang Diminta Perguruan Tinggi

Untuk kriteria kualifikasi yang diminta perguruan tinggi dilakukan dengan menentukan perbandingan berpasangan terhadap alternatif perguruan tinggi untuk menghitung prioritas dan rasio konsistensi. Hasilnya dapat dilihat pada tabel dibawah ini :

Tabel 12. Matriks Perbandingan Kepentingan Alternatif Berdasarkan Pertimbangan Lingkungan Kualifikasi Yang Diminta Perguruan Tinggi

\begin{tabular}{|c|c|c|c|c|}
\hline KUA & A & B & C & Prioritas \\
\hline A & 1 & 0.5 & 1 & 0.25 \\
\hline B & 2 & 1 & 2 & 0.50 \\
\hline C & 1 & 0.5 & 1 & 0.25 \\
\hline
\end{tabular}

$\mathrm{CR}=\mathbf{0}$

f. Kriteria Mutu Kelas

Untuk kriteria mutu kelas dilakukan dengan menentukan perbandingan berpasangan terhadap alternatif perguruan tinggi untuk menghitung prioritas dan rasio konsistensi. Hasilnya dapat dilihat pada tabel dibawah ini :

Tabel 13. Matriks Perbandingan Kepentingan Alternatif Berdasarkan Pertimbangan Mutu Kelas

\begin{tabular}{|c|c|c|c|c|}
\hline KM & A & B & C & Prioritas \\
\hline A & 1 & 6 & 4 & 0.69 \\
\hline B & 0.16 & 1 & 0.33 & 0.09 \\
\hline C & 0.25 & 3 & 1 & 0.22 \\
\hline
\end{tabular}

CR $=0.044$

4. Setelah semua matriks perbandingan kepentingan alternatif selesai diolah maka didapatkan prioritas lokal. Langkah berikutnya adalah melakukan operasi perkalian antara matriks yang memuat prioritas lokal tersebut sehingga akhirnya akan menghasilkan suatu prioritas global. Dari setiap matriks perbandingan kepentingan alternatif, akan didapatkan vektor prioritas 3 * 1 dan karena ada enam matriks perbandingan pada level tersebut maka gabungan vektor-vektor prioritas tersebut akan menghasilkan matriks 3 * 6 , sedangkan pada matriks perbandingan kriteria akan menghasilkan vektor $6 * 1$. Perkalian antara matriks 3 * 6 dengan matriks 6 * 1 akan menghasilkan suatu matriks atau vektor prioritas 3 * 1 yang tidak lain merupakan prioritas global dari semua elemen kepentingan alternatif. Prioritas-prioritas lokal dan prioritas global dari masalah pemilihan perguruan tinggi ditunjukkan pada tabel berikut : 
TELEMATIKA Vol. 06, No. 02, JANUARI $2010: 49-58$

Tabel 14. Prioritas-prioritas Lokal dan Prioritas Global dari Masalah Pemilihan Sekolah

\begin{tabular}{|c|c|c|c|c|c|c|c|}
\hline Kriteria & PBM & LP & KS & PK & KUA & KM & Prioritas \\
Bobot & $\mathbf{0 . 3 0}$ & $\mathbf{0 . 1 4}$ & $\mathbf{0 . 0 3}$ & $\mathbf{0 . 1 3}$ & $\mathbf{0 . 2 1}$ & $\mathbf{0 . 1 4}$ & \\
\hline A & 0.16 & 0.33 & 0.45 & 0.77 & 0.25 & 0.69 & 0.37 \\
\hline B & 0.59 & 0.33 & 0.09 & 0.05 & 0.50 & 0.09 & 0.38 \\
\hline C & 0.25 & 0.33 & 0.46 & 0.17 & 0.25 & 0.22 & 0.25 \\
\hline
\end{tabular}

Berdasarkan tabel 13 maka penilaian dari prioritas kriteria dengan ketiga perguruan tinggi dapat terlihat bahwa perguruan tinggi $B$ memiliki bobot prioritas paling tinggi kemudian disusul oleh perguruan tinggi $A$ dan yang terakhir perguruan tinggi $C$.

\section{Perancangan}

Kegiatan yang dilakukan dalam proses perancangan. Kita melihat data dari sistem dilanjutkan dengan menentukan komponen yang digunakan.

\subsection{Perancangan sistem}

Rancangan digambarkan dalam suatu Diagram Alir Data seperti yang ditunjukkan pada gambar-gambar dibawah ini.menunjukkan proses yang terjadi antara sistem dengan user. Proses tersebut meliputi proses input berupa data goal, data atribut, data alternatif, dan indek kepentingan (bobot). Sedangkan output dari sistem berupa penyajian matrik perbandingan opsi, matrik penghitungan Priority Weight, dan perhitungan prioritas global sekaligus pertimbangan alternatif terbaik.

Pada diagram alir ditunjukan 3 proses, yaitu proses perhitungan AHP meliputi pembobotan sampai dengan perhitungan prioritas lokal. Proses kedua adalah proses perhitungan prioritas global dari atribut dan alternatif yang akan mengkoordinasikan nilai-nilai prioritas lokal atribut maupun alternatif untuk dihitung prioritas global dari tiap alternatif terhadap atributnya. Proses ketiga merupakan proses perhitungan prioritas global yang melakukan perhitungan untuk menentukan prioritas global dari alternatif secara menyeluruh. Hasilnya disimpan dalam tabel global_priority.

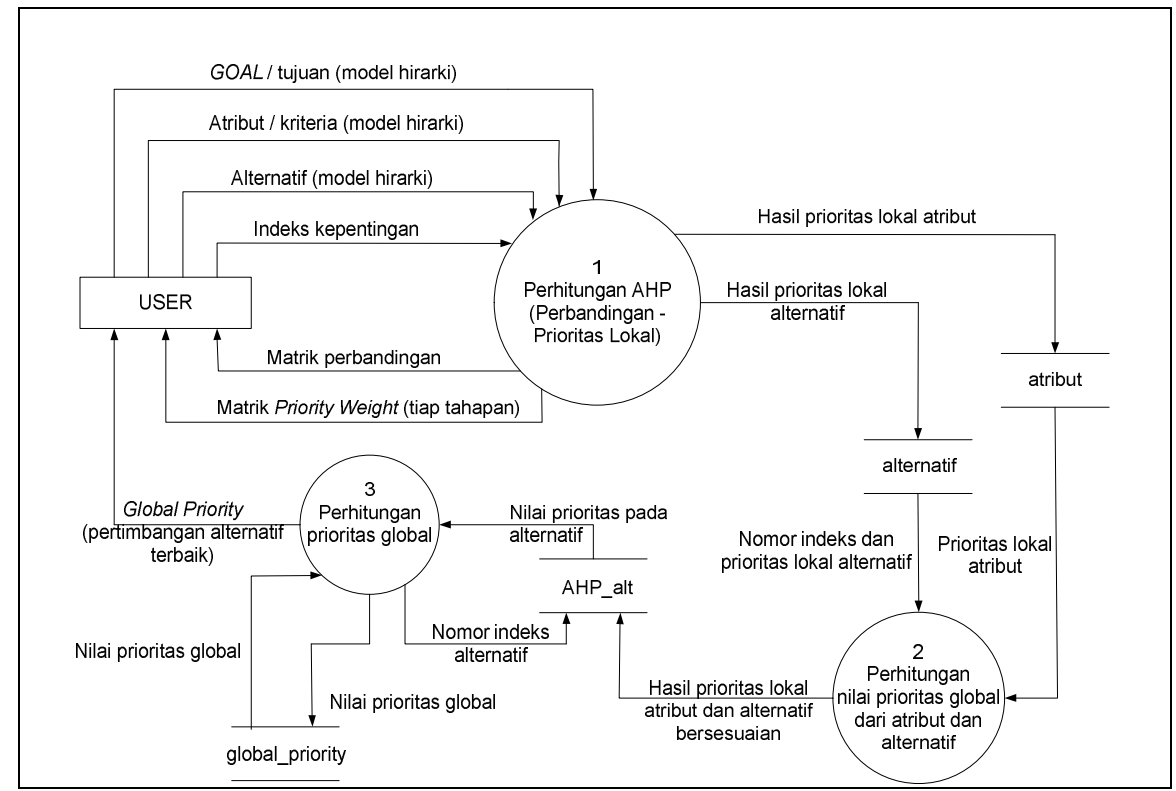

Gambar 2. Diagram Alir AHP

\subsection{Perancangan Basis Data}


Perancangan Basis Data (database) dimaksudkan untuk mengidentifikasi kebutuhan file-file database yang diperlukan serta mengidentifikasi isi atau struktur dari tiap-tiap file. Elemen data disuatu file database harus dapat digunakan untuk pembuatan suatu output, demikian pula input yang akan direkam di database. Penekanan data yang disimpan secara temporary merupakan data yang diperoleh dari perhitungan-perhitungan pada matrik ekuivalen, priority weight, dan prioritas global.

Entitas yang diperlukan digambarkan dalam Diagram Entity-Relationship (Diagram ER). Diagram E-R aplikasi AHP (Analytical Hierarchy Process) adalah seperti berikut ini :

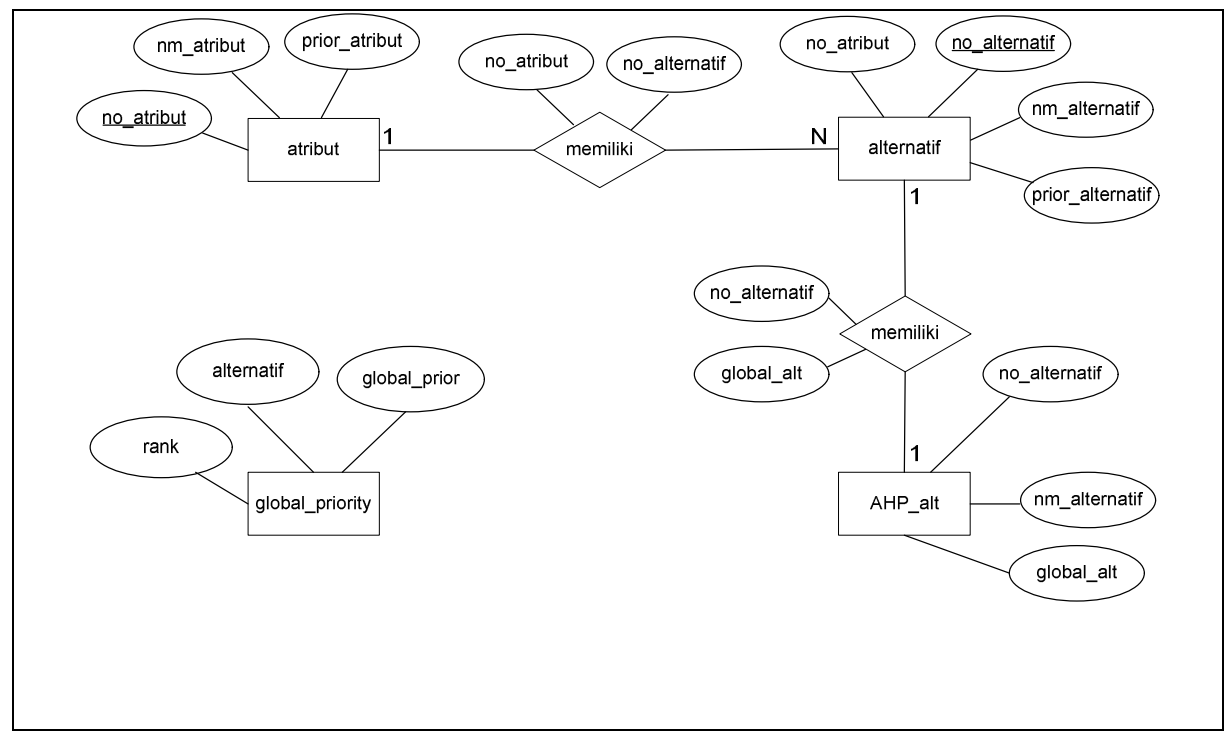

\section{Gambar 3. Diagram E-R AHP}

\subsection{Perancangan user interface}

User Interface merupakan suatu media untuk berinteraksi antara user dengan sistem. Struktur User Interface dapat dilihat pada gambar di bawah:

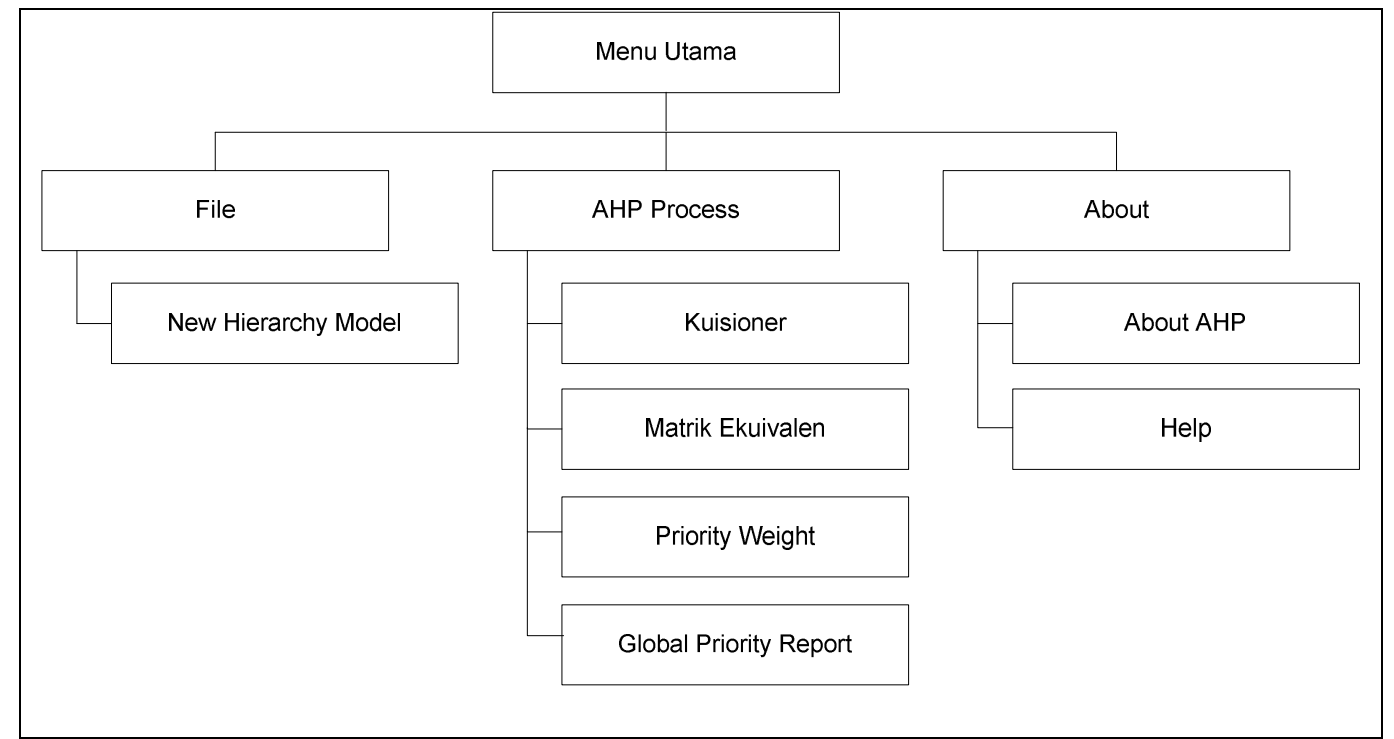

Gambar 4. Rancangan Struktur Halaman AHP

\section{Kesimpulan}


Dengan rancangan tersebut dapat dibangun suatu aplikasi yang dapat digunakan sebagai pendukung pengambilan keputusan. Analytical Hierarchy Process (AHP) merupakan suatu metode yang menerapkan model hirarki fungsional dimana input utamanya adalah persepsi manusia, yang dikaitkan dengan pembandingan bobot kepentingan antara beberapa atribut serta pembandingan beberapa alternatif pilihan. Aplikasi AHP dapat digunakan pengambil keputusan dalam mengolah hirarki kasus untuk menganalisis alternatif terbaik yang bisa diambil. Aplikasi ini dirancang dengan tujuan untuk meningkatkan efisiensi waktu, memberi kemudahan, serta keakuratan perhitungan sebagai penentu ketepatan dalam memberikan pertimbangan alternatif terbaik bagi pengambil keputusan.

\section{Daftar Pustaka}

Daihani, Dadan Umar, 2001, Komputerisasi Pengambilan Keputusan, penerbit PT. Elex Media Komputindo, Jakarta.

Davis, Gordon B., 1999, Kerangka Dasar Sistem Informasi Manajemen, cetakan kesebelas, penerbit PT. Ikrar Mandriabadi, Jakarta.

Fathansyah, 2001, Basis Data, Cetakan ketiga, Penerbit Informatika, Bandung.

Permadi, D.P, 1990, Introduction to Simulation UsingSiman. Mc Graw-Hill, Singapore

Pressman, Rogers, 1997, Rekayasa Perangkat Lunak: Pendekatan Praktisi, Andi Offset, Yogyakarta.

Saaty, TL,1988, Decision Making for Leaders, The Analytical Hierarchy Process for Decision in Complex World, RWS Publications, Pittburrgh

Suryadi, Kadarsah , 2002, Sistem Pendukung Keputusan, Rosda, Bandung. 